Review

\title{
Biotechnology and Conservation of Plant Biodiversity
}

\section{Carlos Alberto Cruz-Cruz ${ }^{1}$, María Teresa González-Arnao ${ }^{1}$ and Florent Engelmann ${ }^{2, *}$}

1 Faculty of Chemistry Sciences, University of Veracruz, Prolongación Oriente 6, No. 1009, Orizaba, Veracruz 94340, México; E-Mails: calcruz@uv.mx (C.A.C.-C.); teregonzalez@uv.mx (M.T.G.-A.)

2 UMR DIADE, Joint Research Unit "Diversity, Adaptation and Development of Plants", IRD (Research Institute for Development), 911 Avenue Agropolis, BP 64501, 34032 Montpellier cedex 5, France

* Author to whom correspondence should be addressed; E-Mail: florent.engelmann@ird.fr; Tel.: +33-4-67-41-62-24; Fax: +33-4-67-41-62-22.

Received: 19 April 2013; in revised form: 5 May 2013 / Accepted: 8 May 2013 /

Published: 4 June 2013

\begin{abstract}
Advances in plant biotechnology provide new options for collection, multiplication and short- to long-term conservation of plant biodiversity, using in vitro culture techniques. Significant progress has been made for conserving endangered, rare, crop ornamental, medicinal and forest species, especially for non-orthodox seed and vegetatively propagated plants of temperate and tropical origin. Cell and tissue culture techniques ensure the rapid multiplication and production of plant material under aseptic conditions. Medium-term conservation by means of in vitro slow growth storage allows extending subcultures from several months to several years, depending on the species. Cryopreservation (liquid nitrogen, $-196{ }^{\circ} \mathrm{C}$ ) is the only technique ensuring the safe and cost-effective long-term conservation of a wide range of plant species. Cryopreservation of shoot tips is also being applied to eradicate systemic plant pathogens, a process termed cryotherapy. Slow growth storage is routinely used in many laboratories for medium-conservation of numerous plant species. Today, the large-scale, routine application of cryopreservation is still restricted to a limited number of cases. However, the number of plant species for which cryopreservation techniques are established and validated on a large range of genetically diverse accessions is increasing steadily.
\end{abstract}

Keywords: biotechnology; conservation; plant biodiversity; in vitro collecting; slow growth storage; cryopreservation; endangered species 


\section{Introduction}

The conservation of plant biodiversity is an important issue concerning the human population worldwide. The anthropogenic pressure, the introduction of alien species, as well as domesticated species and chronic weed infestation have dramatic effects on plant diversity, which is reflected in an increase in the number of threatened species. Plant biodiversity is a natural source of products to the medical and food industries. It provides different basic raw materials and contributes to supply new genetic information useful for breeding programs and for developing more productive crops and more resistant plants to biological and environmental stresses [1].

Conservation of plant biodiversity can be performed in situ or ex situ. The maintenance of plant species in their natural habitat, as well as the conservation of domesticated and cultivated species on the farm or in the surroundings where they have developed their distinctive characteristics represent the in situ strategies [2]. However, there is a heavy loss or decline of species, populations and ecosystem composition, which can lead to a loss of biodiversity, due to habitat destruction and the transformations of these natural environments; therefore, in situ methods alone are insufficient for saving endangered species. Additional approaches, like storage in seed banks, field gene collections, in vitro collections and botanical gardens, complement the preservation programs for plant biodiversity. They are classified as ex situ strategies, which means to maintain the biological material outside their natural habitats [2]. Ex situ conservation is a viable way for saving plants from extinction, and in some cases, it is the only possible strategy to conserve certain species [3]. In situ and ex situ methods are complementary and are not exclusive. They offer different alternatives for conservation, but selection of the appropriate strategy should be based on a number of criteria, including the biological nature of the species and the feasibility of applying the chosen methods [4].

Advances in plant biotechnology, especially those associated to in vitro culture and molecular biology, have also provided powerful tools to support and improve conservation and management of plant diversity [5]. At present, biotechnological methods have been used to conserve endangered, rare, crop ornamental, medicinal and forest species, allowing the conservation of pathogen-free material, elite plants and genetic diversity for short-, medium- and long-term. In vitro conservation is especially important for vegetatively propagated and for non-orthodox seed plant species [6]. Furthermore, in vitro techniques offer a safe mean to internationally exchange plant material, enable the establishment of extensive collections using minimum space, allow supply of valuable material for wild population recovery and facilitate molecular investigations and ecological studies [7].

This review briefly presents the in vitro techniques, which can be efficiently used to improve the conservation of plant biodiversity.

\section{In Vitro Technologies for Collecting Plant Biodiversity}

Plant material collection is the first step to acquire plant germplasm. In vitro techniques can significantly increase collecting efficiency through the use of in vitro collecting, which is the process to initiate tissue cultures in the field [8]. For ex situ conservation, collecting cuttings of plants and seeds is generally the most cost-effective procedure. However, for some species, seeds are sterile or not available, or they have short longevity or viability [8], or they have unusual dormancy requirements 
and propagules may not be easily transported. In some cases, only few individuals of a given species still remain in specific areas; therefore, in vitro collecting of tissues would be less invasive than removing whole plants and will result in a more efficient method for sampling a large number of plants when seeds are not available [9].

Some species cannot be collected by traditional means, due to a seasonal pattern of development. Furthermore, some organs that are not strictly used for propagation, like shoots of trees, are more easily available for collecting at any time [10]. The deterioration of plant material, due to natural processes and microorganism attack, is another limiting factor affecting material integrity [10], and the excessive volume and weight of certain fruits can be a significant problem during the movement of the material collected [10]. Due to the limiting factors mentioned above, in vitro collecting broadens the possibilities for collecting living tissues. In vitro material can be dispatched internationally with fewer restrictions, even though it is still subject to import permits and phytosanitary certificates [8].

The material to be collected depends on each species. Due to cell totipotency, in theory, almost any part of the plant is sufficient to regenerate a whole organism under the appropriate growth conditions. For species producing orthodox seeds, the most common way to acquire plant material is through seed collection; nonetheless, different circumstances, such as seed absence or inadequate seed development, may hinder seed collection and for these cases, zygotic embryos or vegetative tissues, like budwoods, shoots, apices or leaves, can be collected [6]. For vegetatively propagated species, it is necessary to collect stakes, pieces of budwood, tubers or corms [6].

The different factors that must be considered during the in vitro collecting of plant tissue are: the appropriate tissue for in vitro collecting, the size of the tissue, soil residues and presence of diseased tissue, sterilization of plant tissue, removal of the disinfectant, nutrient medium and the conditions of storage, including light, temperature and humidity [10]. Since in vitro collecting is based on tissue culture techniques, its limitations are based on the recalcitrance of some species to regenerate or even to grow in vitro [11]. Furthermore, in vitro collecting may pose more challenges beyond those of normal tissue culture, as work is done in the field and culture exposure to air-borne contaminants may be unavoidable [12].

Microorganism removal is a critical factor that must be strictly controlled during in vitro collecting of plant material. Bacteria and fungi develop rapidly as saprophytes in culture media, and since their nutritional requirements are basically the same as plants, they compete with the plant for nutrients [12]; furthermore, microorganisms can produce phytotoxic metabolites that affect plant growth [13]. Different factors influence the level of explant contamination, like the age of tissues (older tissues are generally more infected than the younger ones), the localization of the tissues (in the air or underground) and the environment [12]. Surface sterilization is the first step in establishing aseptic cultures, which can be done at the collection site or in the laboratory after the tissue sample is placed on a transport medium [12,14]. Systemic antimicrobial agents must be added to the media to kill bacteria or fungi localized beneath the epidermis or in the intercellular spaces, so it is necessary to select the appropriate antibiotic depending on the target microorganism, antibiotic solubility, stability in light, its interactions with other media components and toxicity to humans. Several antibiotics and fungicides used for in vitro plant culture have been detailed and listed by Pence and Sandoval [12]. 
The first in vitro collecting systems were developed for cocoa (Theobroma cacao L.) and coconut (Cocos nucifera L.), generating two in vitro collecting methods that were used as a model to develop other protocols [10].

Cocoa seeds are highly recalcitrant, which represents a challenge for ex situ conservation; furthermore, the material generally used for propagation, mature seeds and cuttings, rapidly lose viability, and it is difficult to maintain alive the material over long distances [15]. In 1987, an in vitro collecting technique was developed for cocoa [16,17].

Collecting coconut seeds by conventional means is a costly and highly inefficient procedure, since seeds are bulky, heavy and highly recalcitrant $[18,19]$. In vitro collecting is based on the premise that the embryo is enough to grow and develop a coconut palm. The adaptation of in vitro culture techniques to collecting coconut embryos had two initial purposes: collecting plant material and the international exchange of coconut germplasm, avoiding the transmission of coconut diseases that are transferred by the nut, but not by the embryo [19]. The available coconut in vitro collecting techniques share some basic steps: the dehusking and cracking open of the nut, the extraction of a plug of endosperm containing the embryo, the dissection of the embryo from the endosperm and the inoculation of the embryo into culture [19]. Different protocols for in vitro collecting of coconut germplasm have been reported [14,20-22]. One of the most recent protocols involves storing the disinfected embryos in a $\mathrm{KCl}$ solution until they arrive to the laboratory; then, they are re-disinfected and inoculated under sterile conditions on semi-solid medium supplemented with sucrose and activated charcoal, placing them in the dark and then transferring cultures to light conditions once the shoots and roots start to develop [23]. Other representative examples of in vitro collecting techniques are presented in Table 1.

Table 1. Representative examples of in vitro collecting technique for selected species.

\begin{tabular}{llc}
\hline \multicolumn{1}{c}{ Species } & \multicolumn{1}{c}{ Explants/Tissue } & Reference \\
\hline Coffea arabica L. (coffee) & Single nodes with axillary buds from orthotropic stems & {$[24]$} \\
Musa L. sp. & Corms from sword shoots & {$[25]$} \\
Citrus L. sp. & Vegetative explants from straight twigs and seeds & {$[26]$} \\
\hline Persea americana Miller (avocado) & & \\
Erythrina L. sp. (flame tree) & Vegetative explants from straight twigs & {$[27]$} \\
Vanilla planifolia Jackson & & \\
Pouteria Aublet sp. (sapodilla) & & {$[28]$} \\
\hline Colocasia esculenta var. esculenta (Taro) & Corms from suckers & {$[29]$} \\
Gossypium hirsutum L. (Cotton) & Stem nodal & \\
\hline
\end{tabular}

In vitro collecting represents an alternative for rare and endangered species, since usually this material is limited in supply and seed collection may be restricted. The removal of small amounts of appropriate tissue from the plant should not harm in situ populations [11]. It will be necessary to develop the appropriate protocol for in vitro collecting depending on the species. A good start will be to take guidance from literature on related species, and sometimes, educated judgments must be taken to develop a procedure for a species with limited amounts of material [11]. 


\section{In Vitro Technologies for Propagation and Exchange of Plant Biodiversity}

The development of biotechnology has led to the production of a new category of germplasm, including clones obtained from elite genotypes, cell lines with special attributes and genetically transformed material [30]. This new germplasm is often of high added value and very difficult to produce. The development of efficient techniques to ensure its safe conservation is therefore of paramount importance.

Tissue culture techniques are of great interest for collecting, multiplication and storage of plant germplasm and are very useful for conserving plant biodiversity, including (a) genetic resources of recalcitrant seed and vegetatively propagated species; (b) rare and endangered plant species; and (c) biotechnology products, such as elite genotypes and genetically engineered material [6,31,32]. Tissue culture systems allow propagating plant material with high multiplication rates in an aseptic environment. Following two alternative morphogenic pathways, shoot organogenesis or somatic embryogenesis, tissue culture has been extensively developed and applied for propagation and regeneration of over 1000 different plant species [33], including numerous rare and endangered species $[34,35]$.

Plant material generated by using in vitro culture techniques is "synchronized", miniaturized and relatively homogenous in terms of size, cellular composition and physiological state [6]. The first requirement for defining any conservation protocol in vitro is the establishment of fully operational tissues culture conditions for regeneration and multiplication of plant material. The factors that determine the response in plant regeneration are environmental, physical and genotypic. Tissue culture techniques should guarantee the generation of abundant material, the recovery of stored samples in high percentages and finally, the development of complete, true-to-type plants.

In vitro techniques have a clear role within ex situ conservation strategies, including for trees and endangered species, particularly where it is important to conserve specific genotypes or where normal propagules, such as recalcitrant seeds may not be suitable for long-term storage. These involve the use of conventional micropropagation systems, slow growth techniques and cryopreservation [36].

In vitro seed germination has been extensively employed for multiplication of a large number of orchid species [37] and could be a rapid mean for multiplying rare and endangered orchids. In vitro seed germination, micropropagation, somatic embryogenesis, zygotic embryo culture and callus culture systems have been developed successfully for a substantial number of native endangered Brazilian species [38]. These systems can be potentially used to further in vitro germplasm conservation studies. Somatic embryogenesis is an important method for mass production of tree species for forestry [39] and for the development of artificial seeds, making handling and direct planting easier [40]. Artificial seeds are encapsulated tissues, such as somatic embryos, shoot tips and axillary buds, which can be used for germplasm conservation. Artificial seeds are used for large scale clonal propagation, breeding of plants producing non-orthodox seeds or non-seed producing plants and facilitate the storage and transportation of samples [41].

Biodiversity hotspots around the globe are at risk and in vitro propagation methods have been used for rescuing and conserving endangered plants [42], in many countries [9], including Australia [43], Malaysia [44] and South Africa [45]. Although standard in vitro propagation methods are, in general, accessible, endangered species may have unusual growth requirements and, thus, may need modified 
procedures for in vitro culture. In addition, the limited amount of plant material available from rare and endangered species poses major challenges in the application of in vitro techniques [35].

It is already well known that micropropagation allows both rapid and massive clonal multiplication of plants; however, it does not ensure that material will be free of systemic agents, such as viruses, which can be present in tissues without manifesting symptoms and spread during the in vitro multiplication. However, among the in vitro techniques, shoot tip or meristem culture has been used for many decades to eliminate viruses in many species from vegetatively propagated plants $[46,47]$. This is based on the uneven distribution of viruses in the youngest tissues of the shoot apex, as their concentration tends to decrease progressively toward the apical meristem of the stem, where the cells are in constant and rapid division $[48,49]$. Since not all cells in a shoot apical meristem are infected with pathogens (e.g., virus, phytoplasmas and endophytic bacteria), it is possible to dissect out a non-infected region and manipulate this explant in vitro to produce virus-free plants [50,51]. As only the meristematic dome and the immediate covering (1st leaf primordia) are usually virus-free [50,51], the size of the meristem excised is critical. Therefore, excision and regeneration of tiny meristems might result in plants free of these pathogens. Regeneration ability is positively proportional to the size of the shoot tip, but pathogen eradication is more efficient using small shoot tips $(0.2-0.4 \mathrm{~mm})$. Hence, pathogen eradication using meristem culture is challenged by the difficulty of excising very small meristems mechanically to remove the infected tissues and of ensuring the survival and regeneration of the tiny meristems $[47,49,52,53]$. Meristem culture, in combination with thermotherapy, facilitates obtaining virus-free plants and ensures an easier production of disease-free stocks [48]. Then, in vitro culture techniques simplify the quarantine procedures for the international exchange of germplasm [6], because the sanitary status of the plants is safe and because it is easier to transport abundant amounts of a miniaturized material. These techniques have been successfully used for many years in virus eradication. Among woody plants, grapevine, apple and peach are the most frequent targets of sanitation protocols, because their health status is strictly regulated. Even when thermotherapy represents the preferred method for the host, viruses can also be eliminated with chemotherapy and tissue culture [54]. Tissue culture techniques have been used for virus elimination on woody, as well as herbaceous plants (Table 2).

Table 2. Representative examples of tissue culture technique used for virus elimination in selected woody and herbaceous plants.

\begin{tabular}{llc}
\hline Species & Virus & Reference \\
\hline $\begin{array}{l}\text { Woody plants } \\
\text { Grapevine }\end{array}$ & $\begin{array}{l}\text { Grapevine fanleaf virus (GFLV) and Grapevine leaf roll-associated virus-1 } \\
\text { (GLRaV-1) }\end{array}$ & {$[55]$} \\
Banana & Banana bract mosaic virus & {$[56]$} \\
Citrus & Citrus psorosis virus & {$[57]$} \\
Cocoa & Cocoa swollen shoot virus & {$[58]$} \\
Rose & Rose mosaic virus & {$[59]$} \\
\hline Herbaceous plants & \\
Sugarcane & Sugarcane mosaic virus (SCMV) and sugarcane yellow leaf virus (ScYLV) & {$[60]$} \\
Garlic & Leek yellow stripe (LYS) and onion yellow dwarf virus (OYDV) & {$[61]$} \\
Potato & Potato leafroll virus (PLRV) and potato virus $Y(P V Y)$ & {$[62]$} \\
\hline
\end{tabular}


Table 2. Cont.

\begin{tabular}{llc}
\hline Species & Virus & Reference \\
\hline Herbaceous plants & \\
Carnation & Carnation latent virus $(C L V)$ & {$[63]$} \\
Chrysanthemum & Cucumber mosaic and tomato aspermy virus & {$[64]$} \\
Dahlia & Dahlia mosaic virus & {$[65]$} \\
Peanut & Peanut mottle potyvirus $(P M V)$ and peanut stripe potyvirus (PStV) & {$[66]$} \\
Pumpkin & Zucchini yellow mosaic virus, cucumber mosaic virus, alfalfa mosaic virus, & \\
& bean yellow mosaic virus & {$[67]$} \\
\hline
\end{tabular}

Collecting, conservation and utilization of plant genetic resources and their international distribution are essential components of international crop improvement programs. This is of special significance in plant movement, quarantine and to breeders who can import a large number of clones of choice, multiply them and distribute them among user groups. In vitro exchange is, therefore, catching on fast. It is important to use suitable, impact resistant and well-sealed culture containers. The packaging should provide adequate thermal insulation and protection against rough handling. The culture medium should be of a formation that includes a higher than usual concentration of gelling agent. The most rapid available shipping method should be preferred [68].

\section{In Vitro Technologies for Conservation of Plant Biodiversity}

In vitro techniques used to achieve medium-term conservation allow the storage of biological material from several months to 2-3 years without subculture, depending on the technique used and on the plant material.

Growth reduction is generally attained by modifying the culture medium and/or the environmental conditions. Modifications of the culture medium can include dilution of mineral elements, reduction of sugar concentration, changes in the nature and/or concentration of growth regulators and addition of osmotically active compounds [6]. As regards the culture environment, it can be changed by reducing the temperature, combined or not, with a decrease in light intensity or by keeping cultures in complete darkness. The most frequently used combination of physical and chemical factors involves decrease of temperature, reduction of mineral elements and carbon source concentration in the medium and the use of low light intensity [69]. The temperatures reported for medium-term conservation are usually from $4{ }^{\circ} \mathrm{C}$ to room temperature [70]. However, tropical plant species are often cold-sensitive and have to be stored in the range of $15-20{ }^{\circ} \mathrm{C}$ or even higher, depending on their sensitivity [71]. Therefore, the procedure to enable extending subculture periods will mainly focus on modifying the chemical composition of culture medium.

Other additional parameters may also influence the efficiency of slow growth storage, such as the type of explants, their physiological state, as well as the type, volume and the kind of closure of culture vessels [31].

Standard in vitro culture conditions can also be used for medium-term storage when dealing with species that have a natural slow growing habit. Alternatively, the explants may be covered with paraffin, mineral oil or with liquid medium to reduce the growth rate. Modifications in gaseous environment, desiccation and/or encapsulation are other possible options [4]. Artificial seeds, which 
are produced by encapsulating plant propagules (shoot buds or somatic embryos) in a synthetic matrix, enable medium-term conservation of various plant species, like orchids, through encapsulation of protocorms [72].

Short- and medium-term conservation is routinely used in many laboratories in order to increase the intervals between subcultures required under the multiplication procedure. At the end of a storage period, cultures are transferred onto fresh medium and usually placed for a short period in optimal conditions to stimulate regrowth before entering the next storage cycle [4].

Slow growth has been successfully used for plant species of both temperate and tropical origin, including crops, forest trees, endangered species and medicinal plants [73,74]. Rare wild species, like Gladiolus imbricatus, which is an important resistance-gene pool in this genus by having resistance to abiotic and biotic stress, was stored up to one year on Murashige and Skoog medium [75], at low temperature and kept in the dark. After one year of storage, $25 \%$ of the plants could be successfully recovered [76].

Musa in vitro plantlets could be conserved at $15^{\circ} \mathrm{C}$ without transfer for up to 15 months [77], while cassava shoot cultures demonstrated to be much more cold-sensitive, since they have to be conserved at temperatures higher than $20^{\circ} \mathrm{C}$ [78]. The same authors reported that cassava shoot cultures could be stored for longer periods in a better condition by increasing the size of the storage containers. Another example related to the effect of culture vessels is the use of heat-sealable polypropylene bags instead of glass test tubes or plastic boxes, which was beneficial for the storage of several strawberry varieties [79].

The presence of a root system improved the storage capacities of coffee plantlets as observed by Kartha et al. [80]. The physiological properties of certain species could suggest that seedlings from recalcitrant seeds of some forest species could possibly be stored under in vitro conditions, which stimulate the under-canopy conditions that arrest development in the wild [36].

By using both mineral oil and silicone oil overlays, it was possible to restrict the growth of sweet potato shoot cultures maintained at $25^{\circ} \mathrm{C}$ [81], and shoot cultures of several ginger species could be conserved for up to two years under mineral oil with high viability [82]. On the other hand, encapsulated grape shoot tips were stored for nine months at $23{ }^{\circ} \mathrm{C}$ [83], and encapsulated date palm somatic embryos were conserved for six months at $4{ }^{\circ} \mathrm{C}$ [84].

The advantage of slow growth techniques is that they use the same basic facilities used for plant micropropagation and that the storage regimes are based on modifying the conditions previously established for rapid multiplication. However, they do not alleviate the main problem associated with the high costs of labor and space requirements of any micropropagation system, in addition to the potential risks of somaclonal variation for some species [36].

\section{Long-Term Conservation through Cryopreservation}

Cryopreservation is the maintenance of living cells, tissues organs and microorganisms at ultralow temperature (usually that of liquid nitrogen, $-196^{\circ} \mathrm{C}$ ). Under cryogenic storage, the biological material can be conserved for extended durations, because at liquid nitrogen temperature, all metabolic activity and cell divisions are stopped and cells will not undergo genetic changes during storage, which may occur when they are maintained by serial subculturing. Furthermore, cryopreserved cells are stored in a small volume, requiring very limited maintenance (topping up storage containers with liquid nitrogen); 
samples are not continuously exposed to the risks of contamination and operator errors, due to frequent manipulations of the plant material [85].

Cryopreservation is the only technique that ensures the safe and cost-efficient long-term conservation of various categories of plants, including non-orthodox seed species, vegetatively propagated plants, rare and endangered species and biotechnology products [6].

In all cryopreservation processes, water removal plays a central role in preventing freezing injury and in maintaining post-thaw viability of cryopreserved material. There are two types of cryopreservation protocols that basically differ in their physical mechanisms: classical cryopreservation procedures, in which cooling is performed in the presence of ice; and the procedures based on vitrification, in which cooling normally takes place without ice formation [86].

Classical freezing procedures involve cryoprotection by using different cryoprotective solutions combined or not with pregrowth of material and followed by slow cooling $\left(0.5-2.0^{\circ} \mathrm{C} / \mathrm{min}\right)$ to a determined prefreezing temperature (usually around $-40{ }^{\circ} \mathrm{C}$ ), rapid immersion of samples in liquid nitrogen, storage, rapid thawing and recovery. They are generally operationally complex, since they require the use of sophisticated and expensive programmable freezers.

Cryopreservation following classical protocols induces a freeze-dehydration process using a slow freezing regime. During the slow temperature decrease, ice is initially formed in the extracellular solution and this external crystallization promotes the efflux of water from the cytoplasm and vacuoles to the outside of the cells where it finally freezes. Therefore, cell dehydration will depend on the cooling rate and the prefreezing temperature set up before immersion of samples to liquid nitrogen [86].

Classical cryopreservation techniques have been successfully applied to undifferentiated culture systems of different plant species, such as cell suspensions and calluses [87,88]. They have also been employed with apices of cold-tolerant plants [89]. Successful cryopreservation of apices from tropical species, such as cassava (Manihot esculenta), is an exceptional example [90,91].

By contrast, the vitrification-based procedures involve cell dehydration prior to cooling by exposure of samples to highly concentrated cryoprotective media (usually called plant vitrification solutions, PVS) and/or by air desiccation. Cooling rate may be rapid or ultra-rapid, depending on how samples are immersed into liquid nitrogen. Vitrification per se is a physical process, defined as the transition of the liquid phase to an amorphous glassy solid at the glass transition ( $\mathrm{Tg}$ ) temperature [92]. This glass may contribute to preventing tissue collapse, solute concentration and $\mathrm{pH}$ alterations during dehydration. Therefore, the freeze-induced dehydration step characteristic of classical procedures is eliminated and the slow freezing regime is replaced by a rapid or ultra-rapid cooling process, characteristic of the vitrification-based protocols.

Several innovations have been implemented in order to increase the cooling rate from the temperature at, which cryoprotective treatments are performed $\left(0\right.$ or $\left.25{ }^{\circ} \mathrm{C}\right)$ and the final storage temperature $\left(-196{ }^{\circ} \mathrm{C}\right)$. In that way, diverse new plant vitrification-based protocols have been developed and are systematically improved. Indeed, most of them are derived from two cryogenic strategies developed since 1990: vitrification [93-95] and encapsulation-dehydration [96,97].

Several vitrification-based procedures are well known at present: pregrowth; dehydration; pregrowth-dehydration; encapsulation-dehydration; vitrification; encapsulation-vitrification; droplet-vitrification [86], and more recently, a new procedure called Cryo-plate is emerging [98]. 
The pregrowth technique consists of cultivating samples in the presence of cryoprotectants, followed by rapid immersion in liquid nitrogen [85]. Dehydration consists of dehydrating explants usually by desiccation in the air current of a laminar airflow cabinet or with silica gel and, then, direct immersion in liquid nitrogen. Pregrowth-dehydration is the combination of the both previously mentioned methods. These techniques are mainly used for cryopreserving meristematic cultures, small size seeds, polyembryonic cultures, zygotic embryos or embryonic axes extracted from seeds, respectively [86].

The encapsulation-dehydration is based on the technology developed for the production of artificial seeds. Explants are encapsulated in alginate beads, pregrown in liquid medium enriched with sucrose for one to seven days, partially desiccated in the air current of a laminar air flow cabinet or with silica gel to a water content around 20\% (fresh weight basis) and then immersed rapidly in liquid nitrogen. Encapsulation of explants allows the application of subsequent drastic dehydration processes prior to cryopreservation, which would otherwise be highly damaging or lethal to non-encapsulated samples. Cryopreservation using the encapsulation-dehydration procedure has been very effective for freezing apices of different plant species from temperate and tropical origin [99].

Vitrification involves treatment of samples with cryoprotective substances (loading), dehydration with highly concentrated plant vitrification solutions (PVS), rapid cooling and rewarming, removal of cryoprotectants and recovery. This procedure has been developed for apices, cell suspensions and somatic embryos of numerous different species [100,101].

Encapsulation-vitrification is a combination of encapsulation-dehydration and vitrification procedures, in which samples are encapsulated in alginate beads and then treated and cooled as under vitrification conditions [100].

Droplet-vitrification is a protocol derived from the combination of the vitrification procedure with the droplet-freezing technique developed by Kartha et al. [102] for cassava shoot tips [86]. Samples are treated with loading and vitrification solutions and then placed on an aluminum foil in minute droplets of vitrification solution or just in one small drop and the aluminum foil strip is directly immersed with the samples in liquid nitrogen [100].

The most recent cryogenic procedure developed, termed cryo-plate [98], combines the encapsulation-dehydration and droplet-vitrification techniques. In this method, shoot tips are attached with a thin calcium alginate layer to an aluminum cryo-plate, loaded, treated with PVS and then cooled by direct immersion of cryo-plates in liquid nitrogen [98,103].

The latest two cryopreservation techniques (droplet-vitrification and cryo-plate) have the common characteristic of providing higher cooling and warming rates compared to other vitrification-based procedures, since samples placed on aluminum foils (with a very high thermal conductivity), are plunged directly into liquid nitrogen for cooling and immersed in a sucrose supplemented medium at room temperature for warming. This significantly increases the probability of obtaining a vitrified state during cooling and of avoiding devitrification during warming [104].

In general, vitrification-based protocols have been very useful for cryopreserving complex organs like shoot-tips and somatic embryos that could not be effectively frozen following classical protocols [105-108]. In addition, the number of species to which they have been successfully applied is increasing steadily, and they are considerably contributing to improve the cryopreservation of tropical plant germplasm [86,100]. 
Cryopreservation of seeds is a very valuable strategy for the long-term conservation of tropical and subtropical forest species biodiversity, as it avoids problems related to embryo isolation and in vitro handling. Even for orthodox and intermediate seeds, cryostorage offers the advantages of seed longevity, so long as liquid nitrogen levels are maintained. Storage of dry seeds at $-20{ }^{\circ} \mathrm{C}$ in seed banks for long periods might also lead to physiological and genetic damages in the very long-term [109].

It is important to realize that the use of cryopreservation should not be restricted to vegetatively propagated plants and non-orthodox seed species. Indeed, recent research findings have shown the necessity to also employ cryopreservation for long-term storage of orthodox seed species. Over the last 30 years, relatively widespread evidence has emerged of less than expected longevity at conventional seed bank temperatures [110]. These authors highlighted the observation that across nearly 200 species, those originating from drier (total rainfall) and warmer temperature (mean annual) locations tended to have greater seed P50 (time taken in storage for viability to fall to 50\%) under accelerated ageing conditions, than species from cool and wet conditions [111]. Moreover, species P50 values were correlated with the proportion of accessions (not necessarily the same species) in that family, which significantly lost viability after 20 years under conditions for long term seed storage, that is, seeds pre-equilibrated with $15 \%$ relative humidity air and then stored at $-20{ }^{\circ} \mathrm{C}$ [112]. Such relative underperformance at $-20{ }^{\circ} \mathrm{C}$ was observed in $26 \%$ of the accessions [111]. In another study, it has been estimated that half-lives for the seeds of 276 species stored for an average of 38 years under $\operatorname{cool}\left(-5{ }^{\circ} \mathrm{C}\right)$ and cold $\left(25\right.$ years at $\left.-18{ }^{\circ} \mathrm{C}\right)$ temperatures was $>100$ years only for $61(22 \%)$ of the species [113]. Nonetheless, cryogenic storage did prolong the shelf life of lettuce (Lactuca) seeds with projected half-lives in the vapor and liquid phases of liquid nitrogen of 500 and 3400 years, respectively [114], up to 20-times greater than that predicted for that species in a conventional seed bank at $-20{ }^{\circ} \mathrm{C}[115,116]$.

Therefore, cryopreservation could be integrated as an extra insurance policy for storing plant biodiversity and could also be considered appropriate for all orthodox seeds. One sub-sample of any accession might be systematically stored in liquid nitrogen, in addition to the samples stored under classical gene bank conditions [117].

There are several examples to illustrate the application of cryopreservation techniques above described to preserve rare and endangered species for various higher plants [32], including orchids [118], bryophytes and ferns [119].

Cryopreservation of seeds of 68 native Western Australian species out of the 90 species tested was successful using a classical protocol involving treatment with dimethyl sulfoxide (DMSO) [120]. Desiccation has been employed for freezing seeds of rare temperate orchids by direct immersion in liquid nitrogen [121]. Several authors have used the desiccation technique for freezing seeds of endangered, rare, ancient and wild Citrus species [73,122,123]. Encapsulation-dehydration has been used for cryopreserving protocorms of Celisostoma areitinum, a rare Thai orchid [124], and shoot-tips of the endemic endangered plant Centaurium rigualii [125]. Turner et al. [126] and Tanaka et al. [127] reported successful cryopreservation of shoot-tips of endangered Australian and Japanese species, respectively, using the vitrification technique. The droplet-vitrification procedure has been used for cryopreserving shoot-tips of wild potatoes [128] and of wild relatives of Diospyros [129].

For vegetatively propagated species, cryopreservation has a major applicability both in terms of species coverage, since protocols have been successfully established for root and tubers, fruit trees, 
ornamentals and plantation crops, both from temperate and tropical origin; and in terms of numbers of genotypes/varieties within a given species [91,130]. In comparison to the results obtained with vegetatively propagated species, the situation for recalcitrant seeds is still at a very preliminary stage. The desiccation technique is mainly employed for freezing embryos and embryonic axes [44]; however, survival is extremely variable and regeneration is frequently restricted to callusing or to incomplete development of plants.

At present, there is a growing number of gene banks and botanic gardens where cryogenic techniques are already employed for different types of materials. Some representative examples of large-scale application of cryopreservation are presented in Table 3.

Table 3. Large-scale application of cryopreservation techniques to different plant germplasm.

\begin{tabular}{|c|c|c|}
\hline Plant material & Gene bank/country & Reference \\
\hline $\begin{array}{l}\text { Seeds of } 1200 \text { accessions from } 50 \text { different } \\
\text { species mainly of endangered medicinal plants }\end{array}$ & $\begin{array}{l}\text { The National Bureau for Plant Genetic } \\
\text { Resources (NBPGR), New Delhi, India }\end{array}$ & {$[131]$} \\
\hline $\begin{array}{l}\text { Seeds of more than } 110 \text { accessions of rare or } \\
\text { threatened species }\end{array}$ & $\begin{array}{l}\text { Kings Park and Botanic Garden, Perth, } \\
\text { Australia }\end{array}$ & {$[132]$} \\
\hline Seeds of coffee involving 450 accessions & IRD Montpellier, France & [133] \\
\hline $\begin{array}{l}\text { Dormant buds of apple involving } \\
2200 \text { accessions }\end{array}$ & $\begin{array}{l}\text { National Center for Genetic Resources } \\
\text { (CNGR), Fort Collins, USA }\end{array}$ & {$[134]$} \\
\hline $\begin{array}{l}\text { Dormant buds of mulberry involving } \\
420 \text { accessions }\end{array}$ & $\begin{array}{l}\text { National Institute of Agrobiological } \\
\text { Resources (NIAR), Yamagata, Japan }\end{array}$ & {$[135]$} \\
\hline Shoot-tips of banana involving 630 accessions & $\begin{array}{l}\text { INIBAP International Transit Center, } \\
\text { Catholic University of Leuven, Belgium }\end{array}$ & {$[136]$} \\
\hline Shoot-tips of cassava involving 540 accessions & $\begin{array}{l}\text { International Center for Tropical Agriculture } \\
\text { (CIAT), Cali, Colombia }\end{array}$ & {$[86]$} \\
\hline Pollen of 13 pear cultivars and 24 Pyrus species & $\begin{array}{l}\text { National Center for Genetic Resources } \\
\text { (CNGR), Fort Collins, USA }\end{array}$ & {$[137]$} \\
\hline $\begin{array}{l}\text { Pollen of more than } 700 \text { accessions of traditional } \\
\text { Chinese flower species }\end{array}$ & $\begin{array}{l}\text { College of Landscape Architecture, Beijing } \\
\text { Forestry University, Beijing, China }\end{array}$ & {$[138]$} \\
\hline $\begin{array}{l}\text { More than } 1000 \text { callus strains of species of } \\
\text { pharmaceutical interest }\end{array}$ & Phytera, Sheffields, UK & [139] \\
\hline $\begin{array}{l}\text { Several thousand conifer embryogenic cell lines } \\
\text { for large-scale clonal planting programs }\end{array}$ & Sylvagen, Vancouver, Canada & {$[140]$} \\
\hline Embryogenic cell lines of coffee and cacao & $\begin{array}{l}\text { Biotechnology Laboratory of the Nestlé } \\
\text { Company, Notre Dame d'Oé, France }\end{array}$ & {$[141]$} \\
\hline
\end{tabular}

\section{Other Uses of Cryopreservation}

Besides germplasm conservation, cryopreservation may be employed to rejuvenate cell and callus cultures, cryoselect plant material with special properties and eliminate viruses from infected plants through apex conservation through a process known as cryotherapy [85].

Galerne et al. [142] mentioned that regrowth of cryopreserved Norway spruce callus was higher compared to that of non-cryopreserved controls. Aguilar et al. [143] showed that production of somatic embryos from cryopreserved Citrus embryogenic callus was higher compared to that of 
non-cryopreserved cultures. This is due to selection performed by liquid nitrogen exposure between different cell types. In cryopreserved samples, liquid nitrogen exposure kills more differentiated cells, which do not participate in culture growth, whereas more meristematic cells, which are responsible for growth, remain alive and reinitiate growth very rapidly and intensely after rewarming. By contrast, non-cryopreserved cell and callus cultures grow more slowly, because of the large proportion of differentiated cells, which do not proliferate actively [85].

Kendall et al. [144] could select freezing tolerant callus of Triticum aestivum by repeating their exposure to liquid nitrogen, and the cryoselected callus regenerated plants with enhanced cold hardiness. The seed progeny of some of the lines tested exhibited significantly enhanced tolerance to $-12{ }^{\circ} \mathrm{C}$, indicating that cryoselection appears to involve, at least in part, selection for genetic rather than epigenetic variants [31]. This could be an interesting strategy to induce cold tolerance in sensitive species.

A novel application of plant cryopreservation techniques is the high frequency pathogen eradication by means of cryotherapy of shoot tips, as first demonstrated by Brison et al. [145]. It eliminates systemic plant pathogens, such as viruses, phytoplasmas and bacteria, by treating shoot tips with liquid nitrogen using cryopreservation protocols. The uneven distribution of viruses and obligate vasculature-limited microbes in shoot tips allows elimination of the infected cells by injuring them with the cryo-treatment and regeneration of healthy shoots from the surviving pathogen-free meristematic cells. Healthy plants are regenerated from the surviving pathogen-free meristematic tissue. It allows treatment of large numbers of samples and results in a high frequency of pathogen-free regenerants. Therefore, it has the potential to replace more traditional methods like meristem culture, chemo- and thermo-therapy $[49,146]$.

To date, severe pathogens have been eradicated in banana (Musa spp.) [147], Citrus spp. [148], grapevine (Vitis vinifera) [149], Prunus spp. [145], raspberry (Rubus idaeus) [150], potato (Solanum tuberosum) [151] and sweet potato (Ipomoea batatas) [52,53,152] using cryotherapy. These pathogens include nine viruses (banana streak virus, cucumber mosaic virus, grapevine virus A, plum pox virus, potato leaf roll virus, potato virus $Y$, raspberry bushy dwarf virus, sweet potato feathery mottle virus and sweet potato chlorotic stunt virus), sweet potato little leaf phytoplasma and Huanglongbing bacterium causing "citrus greening" [49,146].

\section{Conclusions}

In this paper, we have presented the new possibilities offered by biotechnology for improving ex situ conservation of plant biodiversity, through the development of efficient collection, exchange, multiplication, pathogen eradication and conservation methods. These methods are of particular interest for conserving non-orthodox seed and vegetatively propagated species, rare and endangered species, as well as biotechnology products. In recent years, progress has been especially important in the area of cryopreservation, with the development of vitrification-based protocols and with its new application for pathogen eradication by means of cryotherapy.

Optimized conservation strategies should rely on the complementary use of in situ and ex situ techniques. Until recently, ex situ conservation of plant genetic resources has been mostly based on the conservation of seeds in cold chambers and, to a lesser extent, on the maintenance of whole plants in 
field collections. The new biotechnological conservation methods, including in vitro slow growth storage and cryopreservation, need to be systematically integrated in conservation strategies, and the current ex situ conservation concepts should be modified accordingly to accommodate these technological advances. Various criteria should be considered to select the most appropriate methods for conserving a given gene pool, including, notably, the storage characteristics of the species involved, the applicability of the methods chosen in the storage environment, which will vary depending on the available infrastructures, as well as their cost-effectiveness. In many cases, research may still be needed to optimize the methods and to validate them on a range of genetically diverse accessions.

In conclusion, it should be emphasized that the new biotechnology-based conservation techniques developed are not meant to replace conventional ex situ conservation methods. They should be seen as additional tools provided to gene bank and botanic garden curators for optimizing the germplasm collections placed under their responsibility.

\section{Conflict of Interest}

The authors declare no conflict of interest.

\section{References}

1. Rao, N.K. Plant genetic resources: Advancing conservation and use through biotechnology. African J. Biotech. 2004, 3, 136-145.

2. United Nations Conference on Environment and Development (UNCED). Convention on Biological Diversity; UNCED: Geneva, Switzerland, 1992.

3. Ramsay, M.M.; Jacskon, A.D.; Porley, R.D. A Pilot Study for ex Situ Conservation of UK Bryophytes. In Proceedings of EuroGard 2000-II European Botanic Garden Congress, Las Palmas de Gran Canaria, Spain, 10-15 April 2000; Botanic Garden Conservation International: Richmond, UK, 2000; pp. 52-57.

4. Engelmann, F. Germplasm Collection, Storage and Conservation. In Plant Biotechnology and Agriculture; Altman, A., Hasegawa, P.M., Eds.; Academic Press: Oxford, UK, 2012; pp. 255-268.

5. Withers, L.A. Collecting in Vitro for Genetic Resources Conservation. In Collecting Plant Genetic Diversity; Guarino, L., Rao, R., Reid, R., Eds.; Centre for Agricultural Bioscience International: Wallingford, UK, 1995; pp. 511-515.

6. Engelmann, F. Use of biotechnologies for the conservation of plant biodiversity. In Vitro Cell. Dev. Biol. Plant 2011, 47, 5-16.

7. Tandon, P.; Kumaria, S. Prospects of Plant Conservation Biotechnology in India with Special Reference to Northeastern Region. In Biodiversity: Status and Prospects; Tandon, P., Kumaria, S., Eds.; Norasa Publishing House: New Delhi, India, 2005; pp. 79-91.

8. Pence, V.C. In vitro collecting (IVC). I. The effect of collecting method and antimicrobial agents on contamination in temperate and tropical collections. In Vitro Cell. Dev. Biol. Plant 2005, 41, 324-332.

9. Reed, B.M.; Sarasan, V.; Kane, M.; Bunn, E.; Pence, V.C. Biodiversity conservation and conservation biotechnology tools. In Vitro Cell. Dev. Biol. Plant 2011, 47, 1-4. 
10. Withers, L.A. In vitro Collecting-Concept and Background. In In Vitro Collecting Techniques for Germplasm Conservation; Pence, V.C., Sandoval, J.A., Villalobos, V.M., Engelman, F., Eds.; International Plant Genetic Resources Institute: Rome, Italy, 2002; pp. 16-25.

11. Pence, V.C. In vitro Collecting-A Tool for Wild or Endangered Species Conservation. In In Vitro Collecting Techniques for Germplasm Conservation; Pence, V.C., Sandoval, J.A., Villalobos, V.M., Engelman, F., Eds.; International Plant Genetic Resources Institute: Rome, Italy, 2002; pp. 26-29.

12. Pence, V.C.; Sandoval, J.A. Controlling Contamination during in Vitro Collecting. In In Vitro Collecting Techniques for Germplasm Conservation; Pence, V.C., Sandoval, J.A., Villalobos, V.M., Engelman, F., Eds.; International Plant Genetic Resources Institute: Rome, Italy, 2002; pp. 30-40.

13. Falkiner, F. The criteria for choosing an antibiotic for control of bacteria in plant tissue culture. IAPTC Newsl. 1990, 60, 13-23.

14. Rillo, E.P.; Paloma, M.B. Storage and transport of zygotic embryos of Cocos nucifera L. for in vitro culture. Plant Gen. Res. Newsl. 1991, 86, 1-4.

15. Alvarenga, V.S.; Bianchetti, L.B.; López, P.E.; Sandoval, O.E.; Zacher, M.B. Cacao. In In Vitro Collecting Techniques for Germplasm Conservation; Pence, V.C., Sandoval, J.A., Villalobos, V.M., Engelman, F., Eds.; International Plant Genetic Resources Institute: Rome, Italy, 2002; pp. 47-51.

16. Yidana, J.A.; Withers, L.A.; Ivins, J. Development of a simple method for collecting and propagating cocoa germplasm in vitro. Acta Hortic. 1987, 212, 95-98.

17. Yidana, J.A. The Development of in Vitro Collecting and Isozyme Characterization of Cocoa Germplasm. Ph.D. Thesis, University Nottingham, Nottingham, UK, March 1988.

18. Engelmann, F.; Assy-Bah, B.; Bagniol, S.; Dumet, D.; Michaux-Ferriere, N. Cryopreservation of Date Palm, Oil Palm, and Coconut. In Biotecnology in Agriculture and Forestry; Bajaj, Y.P.S., Ed.; Springer-Verlag: Berlin, Germany, 1995; pp. 148-167.

19. Engelmann, F. Coconut. In In Vitro Collecting Techniques for Germplasm Conservation; Pence, V.C., Sandoval, J.A., Villalobos, V.M., Engelman, F., Eds.; International Plant Genetic Resources Institute: Rome, Italy, 2002; pp. 68-71.

20. Ashburner, G.R.; Faure, M.G.; Tomlinson, D.R.; Thompson, W.K. Collection of coconut (Cocos nucifera) embryos from remote locations. Seed Sci. Technol. 1996, 24, 159-169.

21. Samosir, Y.M.S.; Godwin, I.D.; Adkins, S.W. A new technique for coconut (Cocos nucifera) germplasm collection from remote sites: Culturability of embryos following low temperature incubation. Aust. J. Bot. 1999, 47, 69-75.

22. Assy-Bah, B.; Durand-Gasselin, T.; Pannetier, C. Use of zygotic embryo culture to collect germplasm of coconut (Cocos nucifera L.). Plant Genet. Resour. Newsl. 1987, 71, 4-10.

23. Engelmann, F.; Malaurie, B.; N’Nan, O. In Vitro Culture of Coconut (Cocos nucifera L.) Zygotic Embryos. In Plant Embryo Culture: Methods and Protocols, Methods in Molecular Biology Series; Thorpe, T., Yeung, E., Eds.; Humana Press: Totowa, NJ, USA, 2011; pp. 63-74.

24. Lozoya-Saldaña, H.; Oicatá, M.; Borbor-Ponce, M.M.; Calderón-Díaz, J.H. Coffe. In In Vitro Collecting Techniques for Germplasm Conservation; Pence, V.C., Sandoval, J.A., Villalobos, V.M., Engelman, F., Eds.; International Plant Genetic Resources Institute: Rome, Italy, 2002; pp. 42-46.

25. Montoya-Henao, L.M.; Tapia, C.; Espadas, F.L.; Sandoval, G.; Sandoval, J.A. Musa. In In Vitro Collecting Techniques for Germplasm Conservation; Pence, V.C., Sandoval, J.A., Villalobos, V.M., Engelman, F., Eds.; International Plant Genetic Resources Institute: Rome, Italy, 2002; pp. 52-55. 
26. Brenes-Hines, A.; García-Tapia, V.; Velasco-Urquizo, E. Citrus. In In Vitro Collecting Techniques for Germplasm Conservation; Pence, V.C., Sandoval, J.A., Villalobos, V.M., Engelman, F., Eds.; International Plant Genetic Resources Institute: Rome, Italy, 2002; pp. 56-60.

27. Sandoval, J.A.; Villalobos, V.M. Avocado. In In Vitro Collecting Techniques for Germplasm Conservation; Pence, V.C., Sandoval, J.A., Villalobos, V.M., Engelman, F., Eds.; International Plant Genetic Resources Institute: Rome, Italy, 2002; pp. 61-64.

28. Taylor, M. Taro. In In Vitro Collecting Techniques for Germplasm Conservation; Pence, V.C., Sandoval, J.A., Villalobos, V.M., Engelman, F., Eds.; International Plant Genetic Resources Institute: Rome, Italy, 2002; pp. 65-67.

29. Altman, D.W.; Fryxell, P.A.; Koch, S.D.; Howell, C.R. Gossypium germplasm conservation augmented by tissue culture techniques for field collecting. Econ. Bot. 1990, 44, 106-113.

30. Engelmann, F. Cryopreservation of Embryos. In Reproductive Biology and Plant Breeding; Dattée, Y., Dumas, C., Gallais, A., Eds.; Springer Verlag: Berlin, Germany, 1992; pp. 281-290.

31. Engelmann, F. In vitro conservation of tropical plant germplasm-A review. Euphytica 1991, 57, 227-243.

32. Bunn, E.; Turner, S.R.; Panaia, M.; Dixon, K.W. The contribution of in vitro technology and cryogenic storage to conservation of indigenous plants. Austr. J. Bot. 2007, 55, 345-355.

33. Villalobos, V.M.; Engelmann, F. Ex situ conservation of plant germplasm using biotechnology. World J. Microb. Biotechnol. 1995, 11, 375-382.

34. Fay, M.F. Conservation of rare and endangered plants using in vitro methods. In Vitro Cell. Dev. Biol. Plant 1992, 28, 1-4.

35. Sarasan, V.; Cripps, R.; Ramsay, M.M.; Atherton, C.; McMichen, M.; Prendergast, G.; Rowntree, J.K. Conservation in vitro of threatened plants-Progress in the past decade. In Vitro Cell. Dev. Biol. Plant 2006, 42, 206-214.

36. Blakesley, D.; Pask, N.; Henshaw, G.G.; Fay, M.F. Biotechnology and the conservation of forest genetic resources: In vitro strategies and cryopreservation. Plant Growth Regul. 1996, 20, 11-16.

37. Gangaprasad, A.; Decruse, S.W.; Seeni, S.; Menon, V.S. Micropropagation and restoration of endangered Malabar daffodil orchid. Ipsea malabarica. Lindleyana 1999, 14, 47-56.

38. Pilatti, F.K.; Aguiar, T.; Simões, T.; Benson, E.E.; Viana, A.M. In vitro and cryogenic preservation of plant biodiversity in Brazil. In Vitro Cell. Dev. Biol. Plant 2011, 47, 82-98.

39. Kriebel, H.B. Introduction. In Somatic Embryogenesis in Woody Plants; Jain, S.M., Gupta, P.K., Newton, R.J., Eds.; Kluwer Academic: Dordrecht, The Netherlands, 1995; Volume 1, pp. 1-8.

40. Carlson, W.C.; Hartle, J.E. Manufactured Seed of Woody Plants. In Somatic Embryogenesis in Woody Plants; Jain, S., Gupta, P., Newton, R., Eds.; Kluwer Academic Press: London, UK, 1995; Volume 1, pp. 253-263.

41. Ravi, D.; Anand, P. Production and applications of artificial seeds: A review. Int. Res. Biol. Sci. 2012, 1, 74-78.

42. Pence, V.C. In vitro Collection. In A Colour Atlas of Plant Propagation and Conservation; Bowes, B.G., Ed.; Manson Publishing: London, UK, 1999; pp. 87-96.

43. Ashmore, S.E.; Hamilton, K.N.; Offord, C.A. Conservation technologies for safeguarding and restoring threatened flora: Case studies from Eastern Australia. In Vitro Cell. Dev. Biol. Plant 2011, 47, 99-109. 
44. Normah, M.N.; Makeen, A.M. Cryopreservation of Excised Embryos and Embryonic Axes. In Plant Cryopreservation: A Practical Guide; Reed, B., Ed.; Springer: New York, NY, USA, 2008; pp. 211-240.

45. Berjak, P.; Bartels, P.; Benson, E.; Harding, K.; Mycock, D.; Pammenter, N.W.; Sershen; Wesley-Smith, J. Cryoconservation of South African plant genetic diversity. In Vitro Cell. Dev. Biol. Plant 2011, 47, 65-81.

46. Ashmore, S. Status Report on the Development and Application of In Vitro Techniques for the Conservation and Use of Plant Genetic Resources; Engelmann, F., Ed.; International Plant Genetic Resources Institute: Rome, Italy, 1997.

47. Faccioli, V.C.; Marani, F. Virus Elimination by Meristem Tip Culture and Tip Micrografting. In Plant Virus Disease Control; Hadidi, A., Khetarpal, R.K., Koganezawa, H., Eds.; APS Press: St. Paul, MN, USA, 1998; pp. 346-380.

48. Abdelnour-Esquivel, A.; Bermudez, L.C.; Alvarenga, S.; Rivera, C. Cultivo de meristemas, termo y quimioterapia en chayote (Sechium edule Jacq. Sw.) para la erradicación del virus del mosaico del chayote (ChMV) [in Spanish]. Manejo Integr. Plag. Agroecol. Costa Rica 2006, 77, 17-23.

49. Wang, Q.C.; Valkonen, J.P.T. Cryotherapy of shoot tips: Novel pathogen eradication method. Trends Plant Sci. 2009, 14, 199-122.

50. Grout, B.W.W. Meristem-Tip Culture for Propagation and Virus Elimination. In Plant Cell Culture Protocols; Hall, R.D., Ed.; Humana Press Inc.: Totowa, NJ, USA, 1990; pp. 115-125.

51. Kane, M.E. Shoot Culture Procedures. In Plant Development and Biotechnology; Triagiano, R.N., Gray, D.G., Eds.; CRC Press LLC: Boca Raton, FL, USA, 2005; pp. 145-157.

52. Wang, Q.C.; Valkonen, J.P.T. Efficient elimination of sweetpotato little leaf phytoplasma from sweetpotato by cryotherapy of shoot tips. Plant Pathol. 2008, 57, 338-347.

53. Wang, Q.C.; Valkonen, J.P.T. Eradication of two synergistically interacting viruses from sweetpotato using shoot tip culture and cryotherapy of shoot tips. J. Virol. Methods 2008, 154, 135-145.

54. Panattoni, A.; Luvisi, A.; Triolo, E. Review. Elimination of viruses in plants: Twenty years of progress. Span. J. Agric. Res. 2013, 11, 173-188.

55. Youssef, S.A.; Al-Dhaher, M.M.A.; Shalaby, A.A. Elimination of Grapevine fanleaf virus (GFLV) and Grapevine leaf roll-associated virus-1 (GLRaV-1) from infected grapevine plants using meristem tip culture. Int. J. Virol. 2009, 5, 89-99.

56. Ramos, C.S.; Zamora, A.B. Isolation of banana plantlets cv. señorita freed of Banana bract mosaic virus. Philipp. Agric. Sci. 1999, 82, 25-34.

57. D’Onghia, A.M.; Carimi, F.; de Pasquale, F.; Djelouah, K.; Martelli, G.P. Elimination of Citrus psorosis virus by somatic embryogenesis from stigma and style cultures. Plant Pathol. 2001, 50, 266-269.

58. Quainoo, A.K.; Wetten, A.C.; Allainguillaume, J. The effectiveness of somatic embryogenesis in eliminating the Cocoa swollen shoot virus from infected cocoa trees. J. Virol. Methods 2008, 149, 91-96.

59. Golino, D.A.; Sim, S.T.; Lee, J.; Rowhani, A. Elimination of rose mosaic viruses using microshoot tip tissue culture. Acta Hort. 2007, 751, 237-240. 
60. Ramgareeb, S.; Snyman, S.J.; Van-Antwerpen, T.; Rutherford, R.S. Elimination of virus and rapid propagation of diseasefree sugarcane (Saccharum spp. cultivar NCo376) using apical meristem culture. Plant Cell Tissue Org. 2010, 100, 175-181.

61. Ramírez-Malagón, R.; Pérez-Moreno, L.; Borodanenko, A.; Salinas-González, G.J.; Ochoa-Alejo, N. Differential organ infection studies, potyvirus elimination, and field performance of virus-free garlic plants produced by tissue culture. Plant Cell Tissue Org. 2006, 86, 103-110.

62. Fang, Y.; Dhital, S.P.; Li, K.; Khu, D.; Kim, H.; Song, Y.; Lim, H. Utilization of single nodal cuttings and therapies for eradicating double-infected potato virus (PLRV, PVY) from in vitro plantlets of potato (Solanum tuberosum). J. K. Soc. Hort. Sci. 2005, 48, 119-125.

63. Mangal, M.; Bhardwaj, S.V.; Mangal, A.K.; Kaur, R. Production of Carnation latent virus-free stock of carnations. Phytomorphology 2002, 52, 1-6.

64. Kumar, S.; Khan, M.S.; Raj, S.K.; Sharma, A.K. Elimination of mixed infection of Cucumber mosaic and Tomato aspermy virus from Chrysanthemum morifolium Ramat. cv. Pooja by shoot meristem culture. Sci. Hortic. 2009, 119, 108-112.

65. Sedivá, J.; Novák, P.; Laxa, J.; KaÀka, J. Micropropagation, detection and elimination of DMV in the Czech collection of Dahlia. Acta Hort. 2006, 725, 495-498.

66. Morris, J.B.; Dunn, S.; Pinnow, D.L.; Hopkins, M.S.; Pittman, R.N. Meristem culture for virus elimination and peanut interspecific hybrid preservation. Crop Sci. 1997, 37, 591-594.

67. Kabir, A.H.; Pal, S.P.; Sarker, K.K.; Sharmin, S.A.; Alam, M.F. Virus elimination and pathogen-free plantlets regeneration in Cucurbita pepo L. Arch. Phytopathol. PFL 2010, 43, 527-537.

68. Sahijram, L.; Rajasekharan, P.E. Tissue Culture Strategies Applicable to in Vitro Conservation of Tropical Fruit Crops. In Tropical Fruits in Asia: Conservation and Use; IBPGR Progress Report; International Board for Plant Genetic Resources: Rome, Italy, 1996; pp. 113-119.

69. Holobiuc, I.; Paunescu, A.; Blindu, R. Ex situ conservation using in vitro methods in some Caryophyllaceae plant species from the Red List of vascular plants in Romania. Rom. J. Biol. Plant Biol. 2007, 49, 3-16.

70. Tassy, C.; Feuillet, C.; Barret, P. A method for the medium-term storage of plant tissue samples at room temperature and successive cycles of DNA extraction. Plant Mol. Biol. Rep. 2006, 24, 247-248.

71. Paunescu, A. Biotechnology for endangered plant conservation: A critical overview. Rom. Biotech. Lett. 2009, 14, 4095-4103.

72. Devi, J.; Ray, B.K.; Chetia, S.; Deka, P.C. Regeneration of low temperature stored encapsulated protocorms of orchids. J. Orchid. Soc. India 1998, 12, 39-41.

73. Lambardi, M.; Halmagyi, A.; Benelli, C.; de Carlo, A.; Vettori, C. Seed cryopreservation for conservation of ancient Citrus germplasm. Adv. Hortic. Sci. 2007, 21, 198-202.

74. Keshavachandran, R.; Smitha, M.K.; Vijayaraghavan, R. In Vitro Conservation of Endangered Medicinal Plants. In Recent Trends in Horticultural Biotechnology, Volumes I and II, Proceedings of Indian Council of Agricultural Research National Symposium on Biotechnological Interventions for Improvement of Horticultural Crops: Issues and Strategies, Vellanikkara, India, 10-12 January 2005; Keshavachandran, R., Nazeem, P., Girija, D., John, P.S., Peter, K.V., Eds.; Indian Council of Agricultural Research: New Delhi, India, 2005; pp. 439-442. 
75. Murashige, T.; Skoog, F. A revised medium for rapid growth and bioassays with tobacco tissue cultures. Physiol. Plant 1962, 15, 473-497.

76. Rakosy-Tican, E.; Bors, B.; Szatmari, A.M. In vitro culture and medium-term conservation of the rare wild species Gladiolus imbricatus. African J. Biotech. 2012, 11, 14703-14712.

77. Banerjee, N.; de Langhe, E. A tissue culture technique for rapid clonal propagation and storage under minimal growth conditions of Musa (banana and plantain). Plant Cell Rep. 1985, 4, 351-354.

78. Roca, W.M.; Reyes, R.; Beltran, J. Effect of Various Factors on Minimal Growth in Tissue Culture Storage of Cassava Germplasm. In Proceedings of the Sixth Symposium of the International Society for Tropical Root Crops, Lima, Peru, 21-26 February 1984; pp. 441-446.

79. Reed, B.M. Application of gas-permeable bags for in vitro cold storage of strawberry germplasm. Plant Cell Rep. 1991, 10, 431-434.

80. Kartha, K.K.; Mroginski, N.L.; Pahl, K.; Leung, N.L. Germplasm preservation of coffee (Coffea arabica L.) by in vitro culture of shoot apical meristems. Plant Sci. Lett. 1981, 22, 301-307.

81. De Goes, M. Studies on the Conservation of Sweet Potato [Ipomoea batatas (L) LAM] Germplasm. Ph.D. Thesis, University of Bath, Bath, UK, 1993.

82. Dekkers, A.J.; Rao, A.N.; Goh, C.J. In vitro storage of multiple shoot cultures of gingers at ambient temperature. Sci. Hortic. 1991, 47, 157-167.

83. Guanino, T.; Silvanini, A.; Benelli, C.; Beghe, D.; Fabbri, A. Synthetic seed production and conservation of Kober 5BB grapevine rootstock. Ital. Hort. 2009, 16, 267-270.

84. Hamed, A.M.; Gomma, A.H.; Aly, A.S.; Ibrahim, I.A. In vitro storage of encapsuylated somatic embryos of Phenix dactylifera L. Bull. Fac. Agric. Cairo Univ. 2003, 54, 585-598.

85. Engelmann, F. Plant cryopreservation: Progress and prospects. In Vitro Cell. Dev. Biol. Plant 2004, 40, 427-433.

86. Gonzalez-Arnao, M.T.; Panta, A.; Roca, W.M.; Escobar, R.H.; Engelmann, F. Development and large scale application of cryopreservation techniques for shoot and somatic embryo cultures of tropical crops. Plant Cell Tissue Org. Cult. 2008, 92, 1-13.

87. Kartha, K.K.; Engelmann, F. Cryopreservation and Germplasm Storage. In Plant Cell and Tissue Culture; Vasil, I.K., Thorpe, T.A., Eds.; Kluwer: Dordrecht, Germany, 1994; pp. 195-230.

88. Withers, L.A.; Engelmann, F. In Vitro Conservatipon of Plant Genetic Resources. In Biotechnology in Agriculture; Altman, A., Ed.; Marcel Dekker Inc.: New York, NY, USA, 1998; pp. 57-88.

89. Reed, B.M.; Uchendu, E. Controlled Rate Cooling. In Plant Cryopreservation: A Practical Guide; Reed, B.M., Ed.; Springer Verlag: Berlin, Germany, 2008; pp. 77-92.

90. Escobar, R.H.; Mafla, G.; Roca, W.M. A methodology for recovering cassava plants from shoot tips maintained in liquid nitrogen. Plant Cell Rep. 1997, 16, 474-478.

91. Engelmann, F. Importance of Cryopreservation for the Conservation of Plant Genetic Resources. In Cryopreservation of Tropical Plant Germplasm: Current Research Progress and Application; Engelmann, F., Takagi, H., Eds.; Japan International Research Center for Agricultura: Tsukuba, Japan; International Plant Genetic Resources Institute: Rome, Italy, 2000; pp. 8-20.

92. Fahy, G.M.; MacFarlane, D.R.; Angell, C.A.; Meryman, H.T. Vitrification as an approach to cryopreservation. Cryobiology 1984, 21, 407-426. 
93. Langis, R.; Schnabel, B.; Earle, B.J.; Steponkus, P.L. Cryopreservation of carnation shoot tips by vitrification. Cryobiology 1990, 276, 658-659.

94. Sakai, A.; Kobayashi, S.; Oiyama, I. Cryopreservation of nucellar cells of navel orange (Citrus sinensis Osb. var. Brasiliensis Tanaka) by vitrification. Plant Cell Rep. 1990, 9, 30-33.

95. Towill, L.E. Cryopreservation of isolated mint shoot tips by vitrification. Plant Cell Rep. 1990, 9, 178-180.

96. Dereuddre, J.; Scottez, C.; Arnaud, Y.; Duron, M. Resistance of alginate-coated axillary shoot tips of pear tree (Pyrus communis L. cv Beurre Hardy) in vitro plantlets to dehydration and subsequent freezing in liquid nitrogen. C. R. Acad. Sci. Paris 1990, 310, 317-323.

97. Fabre, J.; Dereuddre, J. Encapsulation-dehydration: A new approach to cryopreservation of Solanum shoot tips. CryoLetters 1990, 11, 413-426.

98. Yamamoto, S.; Rafique, T.; Priyantha, W.S.; Fukui, K.; Matsumoto, T.; Niino, T. Development of a cryopreservation procedure using aluminium cryo-plates. CryoLetters 2011, 32, 256-265.

99. Gonzalez-Arnao, M.T.; Engelmann, F. Cryopreservation of plant germplasm using the encapsulation-dehydration technique: Review and case study on sugarcane. CryoLetters 2006, 27, 155-168.

100. Sakai, A.; Engelmann, F. Vitrification, encapsulation-vitrification and droplet-vitrification: A review. CryoLetters 2007, 28, 151-172.

101. Sakai, A.; Hirai, D.; Niino, T. Development of PVS-based Vitrification and Encapsulation-Vitrification Protocols. In Plant Cryopreservation: A Practical Guide; Reed, B.M., Ed.; Springer Verlag: Berlin, Germany, 2008; pp. 33-58.

102. Kartha, K.K.; Leung, N.L.; Mroginski, L.A. In-vitro growth responses and plant regeneration from cryopreserved meristems of cassava (Manihot esculenta Crantz). Z. Pflanzenphysiol. 1982, 107, 133-140.

103. Yamamoto, S.; Rafique, T.; Fukui, K.; Sekizawa, K.; Niino, T. V-cryo-plate procedure as an effective protocol for cryobanks: Case study of mint cryopreservation. CryoLetters 2012, 33, 12-23.

104. Panis, B.; Piette, B.; Swennen, R. Droplet vitrification of apical meristems: A cryopreservation protocol applicable to all Musaceae. Plant Sci. 2005, 168, 45-55.

105. Panis, B. Cryopreservation of Banana (Musa spp.) Germplasm. Ph.D. Thesis, Catholoc University of Leuven, Leuven, Belgium, February 1995.

106. Gonzalez-Arnao, M.T.; Engelmann, F.; Huet, C.; Urra, C. Cryopreservation of encapsulated apices of sugarcane: Effect of freezing procedure and histology. CryoLetters 1993, 14, 303-308.

107. Gonzalez-Arnao, M.T.; Ravelo, M.M.; Urra-Villavicencio, C.; Montero, M.M.; Engelmann, F. Cryopreservation of pineapple (Ananas comosus) apices. CryoLetters 1998, 19, 375-382.

108. Gonzalez-Arnao, M.T.; Juarez, J.; Ortega, C.; Navarro, L.; Duran-Vila, N. Cryopreservation of ovules and somatic embryos of citrus using the encapsulation-dehydration technique. CryoLetters 2003, 24, 85-94.

109. Stanwood, P.C.; Bass, L.N. Seed germplasm preservation using liquid nitrogen. Seed Sci. Technol. 1981, 9, 423-437.

110. Li, D.Z.; Pritchard, H.W. The science and economics of ex situ plant conservation. Trends Plant Sci. 2009, 14, 614-621. 
111. Probert, R.J.; Daws, M.I.; Hay, F. Ecological correlates of ex situ seed longevity: A comparative study on 195 species. Ann. Bot. 2009, 104, 57-69.

112. Food and Agriculture Organization of the United Nations; International Plant Genetic Resources Institute. Genebank Standards; Food and Agriculture Organization of the United Nations: Rome, Italy; International Plant Genetic Resources Institute: Rome, Italy, 1994; pp. 1-17.

113. Walters, C.; Wheeler, L.J.; Grotenhuis, J.M. Longevity of seeds stored in a genebank: Species characteristics. Seed Sci. Res. 2005, 15, 1-20.

114. Walters, C.; Wheeler, L.J.; Stanwood, P.C. Longevity of cryogenically stored seeds. Cryobiology 2004, 48, 229-244.

115. Roberts, E.H.; Ellis, R.H. Water and seed survival. Ann. Bot. 1989, 63, 39-52.

116. Dickie, J.B.; Ellis, E.H.; Kraak, H.L.; Ryder, K.; Tompsett, P.B. Temperature and seed storage longevity. Ann. Bot. 1990, 65, 197-204.

117. Pritchard, H.W.; Ashmore, S.; Berjak, P.; Engelmann, F.; González-Benito, M.E.; Li, D.Z.; Nadarajan, J.; Panis, B.; Pence, V.; Walters, C. Storage Stability and the Biophysics of Preservation. In Proceedings of the Plant Conservation for the Next Decade: A Celebration of Kew's 250th Anniversary, Royal Botanic Garden Kew, London, UK, 12-16 October 2009; p. 11.

118. Hirano, T.; Ishikawa, K.; Mii, M. Advances in Orchid Cryopreservation. In Floriculture, Ornamental and Plant Biotechnology, Advances and Topical Issues; Teixeira da Silva, J.A., Ed.; Global Science Books: Kenobe, Japan, 2006; Volume 2, pp. 410-414.

119. Pence, V.C. Cryopreservation of Bryophytes and Ferns. In Plant Cryopreservation: A Practical Guide; Reed, B.M., Ed.; Springer Verlag: Berlin, Germany, 2008; pp. 117-140.

120. Touchell, D.H.; Dixon, K.W. Cryopreservation of seed of Western Australia native species. Biodiv. Cons. 1993, 2, 594-602.

121. Nikishina, T.V.; Popova, E.V.; Vakhrameeva, M.G.; Varlygina, T.I.; Kolomeitseva, G.L.; Burov, A.V.; Popovich, E.A.; Shirokov, A.I.; Shumilov, V.; Yu, V.; et al. Cryopreservation of seeds and protocorms of rare temperate orchids. Russ. J. Plant Physiol. 2007, 54, 121-127.

122. Malik, S.K.; Chaudhury, R. The cryopreservation of embryonic axes of two wild and endangered Citrus species. Plant Genet. Res. Charact. Util. 2006, 4, 204-209.

123. Hamilton, K.N.; Ashmore, S.E.; Pritchard, H.W. Thermal analysis and cryopreservation of seeds of Australian wild Citrus species (Rutaceae): Citrus australasica, C. inodora and C. garrawayi. CryoLetters 2009, 30, 268-279.

124. Maneerattanarungroj, P.; Bunnag, S.; Monthatong, M. In vitro conservation of Cleisostoma areitinum (Rchb. f.) Garay, rare Thai orchid species by an encapsulation-dehydration method. Asian J. Plant Sci. 2007, 6, 1235-1240.

125. Gonzalez-Benito, M.E.; Perez, C. Cryopreservation of nodal explants of an endangered plant species (Centaurium rigualii Esteve) using the encapsulation-dehydration method. Biodiv. Cons. 1997, 6, 583-590.

126. Turner, S.R.; Senaratna, T.; Bunn, E.; Tan, B.; Dixon, K.W.; Touchell, D.H. Cryopreservation of shoot tips from six endangered Australian species using a modified vitrification protocol. Ann. Bot. 2001, 87, 371-378. 
127. Tanaka, D.; Niino, T.; Tsuchiya, Y.; Shirata, K.; Uemura, M. Cryopreservation of shoot tips of endangered Hayachine-usuyukiso [Leontopodium hayachinense (Takeda) Hara et Kitam.] using a vitrification protocol. Plant Genet. Res. Charact. Util. 2009, 6, 164-166.

128. Yoon, J.W.; Kim, H.H.; Cho, E.G.; Ko, H.C.; Hwang, H.S.; Park, Y.E.; Engelmann, F. Cryopreservation of cultivated and wild potato varieties by droplet vitrification procedure. Acta Hortic. 2007, 760, 203-208.

129. Niu, Y.L.; Luo, Z.R.; Zhang, Y.F. Studies on cryopreservation of two Diospyros spp. germplasm by modified droplet vitrification. J. Wuhan Bot. Res. 2009, 27, 451-454.

130. Benelli, C.; de Carlo, A.; Engelmann, F. Recent advances in the cryopreservation of shoot-derived germplasm of economically important fruit trees of Actinidia, Diospyros, Malus, Olea, Prunus, Pyrus and Vitis. Biotech. Adv. 2013, 31, 175-185.

131. Mandal, B.B. Cryopreservation Research in India: Current Status and Future Perspectives. In Cryopreservation of Tropical Plant Germplasm-Current Research Progress and Applications; Engelmann, F., Takagi, H., Eds.; Japan International Research Center for Agricultura: Tsukuba, Japan; International Plant Genetic Resources Institute: Rome, Italy, 2000; pp. 282-286.

132. Touchell, D.H.; Dixon, K.W. Cryopreservation for seedbanking of Australian species. Ann. Bot. 1994, 40, 541-546.

133. Dussert, S.; Couturon, E.; Bertrand, B.; Nuissier, F.; Joët, T.; Pavis, C.; Engelmann, F. Progress in the Implementation of the French Coffee Cryobank. In Proceedings of the 2nd International Symposium on Plant Cryopreservation, Fort Collins, CO, USA, 11-14 August 2013; in press.

134. Forsline, P.L.; McFerson, J.R.; Lamboy, W.F.; Towill, L.E. Development of base and active collections of Malus germplasm with cryopreserved dormant buds. Acta Hort. 1999, 484, 75-78.

135. Niino, T. Cryopreservation of Germplasm of Mulberry. In Biotechnology in Agriculture and Forestry, Volume 32, Cryopreservation of Plant Germplasm I; Bajaj, Y.P.S., Ed.; Springer Verlag: Berlin, Germany, 1995; pp. 102-113.

136. Panis, B.; van den Houwe, I.; Piette, B.; Swennen, R. Cryopreservation of the Banana Germplasm Collection at the ITC (INIBAP Transit Centre). In Proceedings of the 1st Meeting of COST 871 Working Group 2: Technology, Application and Validation of Plant Cryopreservation, Florence, Italy, 10-13 May 2007; pp. 34-35.

137. Reed, B.M.; DeNoma, J.; Chang, Y. Application of Cryopreservation Protocols at a Clonal Genebank. In Cryopreservation of Tropical Plant Germplasm-Current Research Progress and Applications; Engelmann, F., Takagi, H., Eds.; Japan International Research Center for Agricultura: Tsukuba, Japan; International Plant Genetic Resources Institute: Rome, Italy, 2000; pp. 246-249.

138. Li, B.L.; Zhang, Y.L.; Wang, H.; Song, C.H.; Liu, Y. Pollen cryo-bank establishment and application of traditional chinese flowers. Cryobiology 2009, 59, 414.

139. Spencer, $M$. The challenges of developing cryopreservation strategies to suit the requirements of a large industrial in vitro plant cell collection. Cryobiology 1999, 39, 325.

140. Cyr, D.R. Cryopreservation: Roles in Clonal Propagation and Germplasm Conservation of Conifers. In Cryopreservation of Tropical Plant Germplasm-Current Research Progress and Applications; Engelmann, F., Takagi, H., Eds.; Japan International Research Center for Agricultura: Tsukuba, Japan; IPGRI: Rome, Italy, 2000; pp. 261-268. 
141. Florin, B.; Brulard, E.; Lepage, B. Establishment of a cryopreserved coffee germplasm bank. Cryobiology 1999, 39, 309.

142. Galerne, M.; Bercetche, J.; Dereuddre, J. Cryoconservation of embryogenic cellus of Norway spruce (Picea abies L. Karst) - Influence of different factors on callus recovery and on embryos and plantlet production. Bull. Soc. Fr. Lett. Bot. 1992, 4-5, 331-344.

143. Aguilar, M.E.; Engelmann, F.; Michaux-Ferrière, N. Cryopreservation of embryogenic cell suspensions of Citrus deliciosa Tan. and histological study. CryoLetters 1993, 14, 217-228.

144. Kendall, E.J.; Qureshi, J.A.; Kartha, K.K.; Leung, N.; Chevrier, N.; Caswell, K.; Chen, T.H.H. Regeneration of freezing-tolerant spring wheat (Triticum aestivum L.) plants from cryoselected callus. Plant Physiol. 1990, 94, 1756-1762.

145. Brison, M.; de Boucaud, M.T.; Pierronnet, A.; Dosba, F. Effect of cryopreservation on the sanitary state of a cv of Prunus rootstock experimentally contaminated with Plum Pox Potyvirus. Plant Sci. 1997, 123, 189-196.

146. Wang, Q.C.; Panis, B.; Engelmann, F.; Lambardi, M.; Valkonen, J.T. Cryotherapy of shoot tips: A technique for pathogen eradication to produce healthy planting materials and prepare healthy plant genetic resources for cryopreservation. Ann. Appl. Biol. 2009,154, 351-363.

147. Helliot, B.; Panis, B.; Poumay, Y.; Swennen, R.; Lepoivre, P.; Frison, E. Cryopreservation for the elimination of cucumber mosaic and banana streak viruses from banana (Musa spp.). Plant Cell Rep. 2002, 20, 1117-1122.

148. Ding, F.; Jin, S.; Hong, N.; Zhong, Y. Vitrification-cryopreservation, an efficient method for eliminating Candidatus Liberobacter asiaticus, the citrus Huanglongbing pathogen, from in vitro adult shoot tips. Plant Cell Rep. 2008, 27, 241-250.

149. Wang, Q.C.; Mawassi, M.; Li, P.; Gafny, R.; Sela, I.; Tanne, E. Elimination of grapevine virus A (GVA) by cryopreservation of in vitro-grown shoot tips of Vitis vinifera L. Plant Sci. 2003, 165, 321-327.

150. Wang, Q.C.; Cuellar, W.J.; Rajamäki, M.L.; Hirata, Y.; Valkonen, J.P.T. Combined thermotherapy and cryotherapy for virus eradication: Relation of virus distribution, subcellular changes, cell survival and viral RNA degradation in shoot tips to efficient production of virus-free plants. Mol. Plant Pathol. 2008, 9, 237-250.

151. Wang, Q.C.; Liu, Y.; Xie, Y.; You, M. Cryotherapy of potato shoot tips for efficient elimination of potato leaf roll virus (PLRV) and potato virus Y (PVY). Potato Res. 2006, 49, 119-129.

152. Feng, C.; Yin, Z.; Ma, Y.; Zhang, Z.; Chen, L.; Wang, B.; Li, B.; Huang, Y.; Wang, Q. Cryopreservation of sweetpotato (Ipomoea batatas) and its pathogen eradication by cryotherapy. Biotech. Adv. 2011, 29, 84-93.

(C) 2013 by the authors; licensee MDPI, Basel, Switzerland. This article is an open access article distributed under the terms and conditions of the Creative Commons Attribution license (http://creativecommons.org/licenses/by/3.0/). 